\title{
HEAVY METAL POLLUTION OF FOREST SOILS AFFECTED BY THE COPPER INDUSTRY
}

\author{
Agnieszka Medyńska-Juraszek, Cezary Kabała \\ Institute of Soil Sciences and Environmental Protection, \\ Wroclaw University of Environmental and Life Sciences
}

\begin{abstract}
The study was carried out on forest soils in the vicinity of a copper ore tailings facility and a copper smelter in Lower Silesia, Poland. Soil and litter samples were collected in the surroundings of the tailings facility under pine stands different in age (50,18 and 11 years old) and under poplar stands (same age as the pine stands) located at an increasing distance from the copper smelter $(0.5 \mathrm{~km}, 1.5 \mathrm{~km}$ and $2.1 \mathrm{~km})$. The purpose of the study was to describe the effect of copper mining and smelting on forest soils. The following were determined in the collected soil and litter samples: $\mathrm{pH}$ in distilled water electrometrically with a $\mathrm{pH}$ meter and total concentrations of $\mathrm{Cu}, \mathrm{Zn}$ and $\mathrm{Pb}$ after digestion with perchloric acid (1:10) using the ICP-ES technique. Very high $\mathrm{pH}$ values were found in all organic horizons, which can evidence the alkalizing effect of dusts from the objects. In all the forest soils, the highest total concentrations of all the analyzed elements were found in humus layers, decreasing in deeper horizons of the soil profile. The total concentration of $\mathrm{Cu}, \mathrm{Pb}$ and $\mathrm{Zn}$ was much higher in forest soils under poplar stands in the vicinity of the copper smelter. The concentration of all the elements decreased rapidly with the distance from the smelter. The concentration of $\mathrm{Cu}, \mathrm{Pb}$ and $\mathrm{Zn}$ was higher than found in the vicinity of the objects on the arable soils. This can indicate a secondary rise in heavy metal concentration in the topsoil caused by the presence of a tree stand.
\end{abstract}

Key words: forest soils, litter, copper smelter, heavy metals.

Agnieszka Medyńska-Juraszek, Ph.D., Institute of Soil Sciences and Environmental Protection, Wroclaw University of Environmental and Life Sciences, Grunwaldzka 53, 50-357 Wrocław, Poland, e-mail: agnieszka.medynskajuraszek@up.wroc.pl 


\title{
ZANIECZYSZCZENIE METALAMI CIĘŻKIMI GLEB LEŚNYCH W REJONIE ODDZIALYWANIA PRZEMYSŁU MIEDZIOWEGO
}

\begin{abstract}
Abstrakt
Badania prowadzono na obszarach leśnych stanowiących dawną strefę ochronną składowiska odpadów flotacji rud miedzi oraz huty miedzi. Powierzchnie badawcze w rejonie składowiska odpadów zlokalizowano pod różnowiekowymi drzewostanami sosnowym (50, 18 i 11 lat). W rejonie huty miedzi powierzchnie zlokalizowano $\mathrm{w}$ funkcji odległości od źródła emisji $(0,5 \mathrm{~km}, 1,5 \mathrm{~km}$ i $2,1 \mathrm{~km}$ od huty) w równowiekowych drzewostanach topolowych. Celem pracy było określenie wpływu przemysłu miedziowego na gleby leśne w rejonach objętych znacznym oddziaływaniem ww. obiektów. Na każdej powierzchni badawczej pobrano próbki gleb i ektopróchnic, w których analizowano $\mathrm{pH}$ w wodzie destylowanej i całkowita zawartość $\mathrm{Cu}, \mathrm{Pb}$ i $\mathrm{Zn}$ po mineralizacji w kwasie nadchlorowym (1:10) z użyciem metody ICP-ES. Bardzo wysokie wartości $\mathrm{pH}$ stwierdzone w ektopróchnicach świadczą o alkalizującym wpływie emisji pochodzących z obu obiektów. W ektopróchnicach wszystkich badanych gleb stwierdzono najwyższa całkowita zawartość $\mathrm{Cu}, \mathrm{Zn}$ i $\mathrm{Pb}$, a zawartość pierwiastków malała w głąb profilu glebowego. Całkowita zawartość badanych pierwiastków była zdecydowanie wyższa $\mathrm{w}$ glebach $\mathrm{w}$ rejonie huty miedzi i wyraźnie malała wraz ze wzrostem odległości od źródła emisji. Zawartość $\mathrm{Cu}, \mathrm{Zn}$ i Pb była zdecydowanie wyższa niż stwierdzona w tym rejonie zawartość pierwiastków w glebach uprawnych. Może to świadczyć o wtórnym nagromadzeniu $\mathrm{Cu}, \mathrm{Zn}$ i $\mathrm{Pb}$ w glebach obszarów zadrzewionych.
\end{abstract}

Słowa kluczowe: gleby leśne, ściółka, huta miedzi, metale ciężkie.

\section{INTRODUCTION}

Mining and smelting can be a significant source of metal contamination of the environment due to mineral excavation, ore transportation, ore flotation, smelting and refining and disposal of tailings and wastewater around mines and smelters. Heavy metal pollution of soils in the Legnica-Głogów copper mining area has been the subject of several investigations in recent years (ANDruszczaK et al. 1986, Szerszeń et al. 1999, ANGęow et al. 2000, Szerszeń et al. 2004, KabAŁA et al. 2008, MedyŃSKa et al. 2009, KarCZEWsKa et. al. 2010). Many of these studies focused on arable soils and the effect on crop productivity. These days, most of the lands in the nearest surroundings of copper mining and smelting objects are afforested, but our knowledge on heavy metal pollution of forest soils is very modest. Forest ecosystems efficiently filter pollutant particles from the air (UkONOMAANAHO et al. 2001). The presence of humus layers in forest soils has often been found to effectively retain heavy metals, particularly $\mathrm{Pb}$ and $\mathrm{Cu}$ (Bergkvist et al. 1989, Derome, NiEMinen 1998). Therefore, forest ecosystems and forest soils can accumulate considerable amounts of trace elements. In this paper, we are describing the effect of copper mining and smelting on forest soils. 


\section{MATERIALS AND METHODS}

The study was carried out on forest soils affected by dusts from two emission sources: a copper ore tailings facility and a copper smelter. The tailings facility (impoundment) has been exploited since 1977. Over $368 \mathrm{mln}$ $\mathrm{m}^{3}$ of tailings from copper ore flotation have been deposited over an area of 1390 ha. Because of their physical properties and the storage technology, tailings are the most significant source of the local soil pollution. The main problem is the emission of dust from dry beaches surrounding the pond. Dust containing excessive amounts of heavy metals such as $\mathrm{Cu}, \mathrm{Pb}, \mathrm{Zn}, \mathrm{Cd}$, $\mathrm{Ni}$ and As becomes a potential source of soil and plant contamination. Since 1996, sixty-four sites (mostly arable soils) in the environs of the facility have been monitored. The results show long-term changes in the heavy metal contamination of the soils affected by the facility.

The copper smelter belongs to a mining and smelting complex founded in 1951, which currently includes 4 mines, 3 ore enrichment plants and 3 smelters. The complex produces approximately 500000 tons of copper annually, a quarter of which is produced in the Legnica Smelter. The copper smelting plant in Legnica opened in 1953 and in the past was indicated as a source of high metal-containing dust emission, which was considerably reduced in the 1980s and 1990s in all the facilities of the complex (Monograph of KGHM 2007). However, the long-term pollution caused by the Legnica Copper Smelter has led to extensive soil contamination with many trace elements. In the early 1980 s, the most severely contaminated soils within the so-called impact areas were planted with black poplar (Populus nigra L.) and black Italian poplar (Populus euroamericana f. serotina Hartig).

Soil and litter samples were collected from six forest sites. Three study sites were located in pine forests, in the surroundings of the Zelazny Most tailings facility (ZM), about the same distance from the smelter (approximately $400 \mathrm{~m}$ ), east and north-east of the object (Figure 1). The coniferous stands were of different age: $50(1 \mathrm{ZM}), 18$ years old $(2 \mathrm{ZM})$ and 11 years old (3 ZM). Three other sites were located in the former impact area of the Legnica Copper Smelter (HML), in poplar plantings $0.5 \mathrm{~km}, 1.5 \mathrm{~km}$ and $2.1 \mathrm{~km}$ from the emitter (Figure 1). Litter samples were collected with a steel cylinder $(d=23 \mathrm{~cm})$, in four replicates. Soil profiles were made in May 2009 and samples were collected from each horizon for further analysis. The soil and litter samples were submitted to the following determinations: $\mathrm{pH}$ in distilled water electrometrically with a pH meter (CARTER, GREGORICH 2008), the total concentration of $\mathrm{Cu}, \mathrm{Zn}$ and $\mathrm{Pb}$ after mineralization with perchloric acid (1:10) in an open column system (HOSSNER 1996) using the ICP-ES technique. All analysis were made in two replications. 


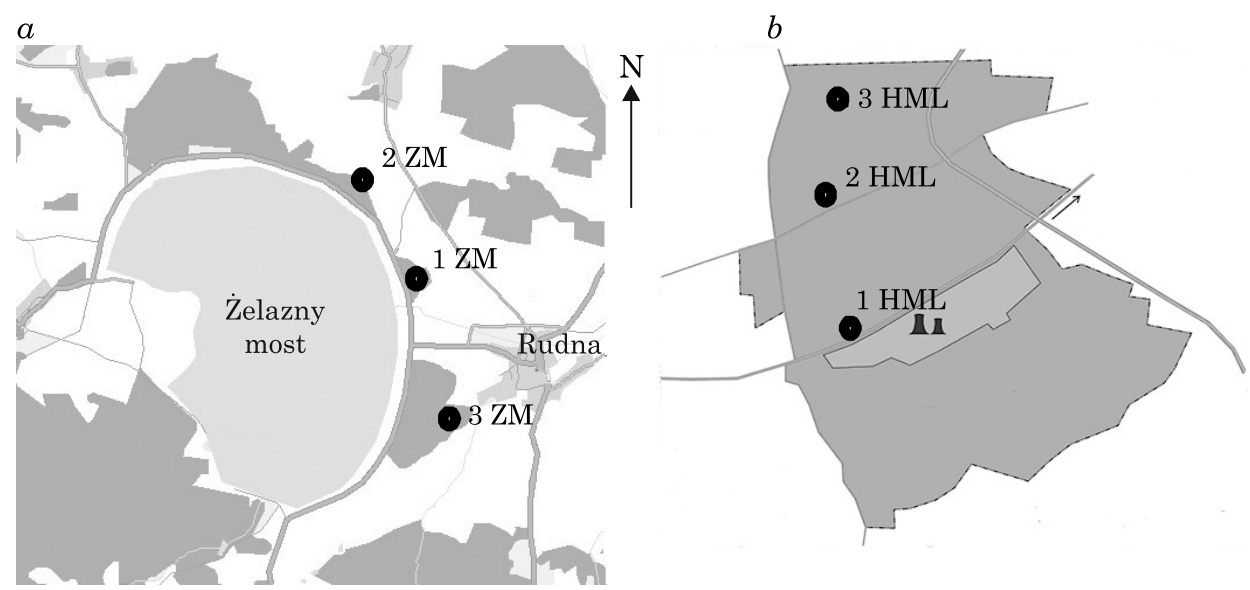

Fig. 1. Location of the study sites $a$ ) in the vicinity of the copper ore tailings facility in Zelazny Most, $b$ ) in the vicinity of the copper smelter in Legnica

\section{RESULTS AND DISCUSSION}

Forest soils in the surroundings of the copper ore tailings facility were Brunic Arenosols (Fao-Wrb 2007) developed from poor, loose sands with (proto)moder humus in different stages of development. Forest soils in the surroundings of the copper smelter were Cutanic Luvisols (FAO-WRB 2007) developed from loess-like sediments, having the texture of silt loam, mostly with mull humus. In all the forest soils, the $\mathrm{pH}$ values in the $0-30 \mathrm{~cm}$ topsoil and organic layers were higher than found in natural, unpolluted forest ecosystems (ŚwiERCZ 2003, MERTENs et al. 2007). Under coniferous tree stands (ZM) in the vicinity of the copper ore tailings facility, the $\mathrm{pH}$ reached 6.6 in $\mathrm{O}$ horizon (Table 1). The high soil $\mathrm{pH}$ was caused by two factors 1) high input of airborne calcium and magnesium from dusts from the copper tailings facility 2) high calcium content in parent rock of these soils. Previous studies demonstrated a high calcium and magnesium content in dust from the copper ore tailings facility as well as a high calcium carbonate content in $\mathrm{C}$ horizons. Soil under coniferous stands differed in the $\mathrm{pH}$ values between the sites. The $\mathrm{pH}$ of organic horizons increased with the age of a tree stand and was the highest under the 50-year-old tree stand ZM (Table 1). More acidic $\mathrm{O}$ horizons were found under the youngest tree stand, which could have been caused by the accumulation of non-decomposed organic matter, consisting mainly of fresh pine needles. Among the mineral horizons of the profiles, the highest $\mathrm{pH}$ - up to 7.1 - was determined under the 18-year old stand $2 \mathrm{ZM}$, and the lowest one - under the 50-year old 
Table 1

Chemical properties of forest soils in the surrounding of the copper ore tailings impoundment

\begin{tabular}{|c|c|c|c|c|c|c|}
\hline \multirow{2}{*}{ Profile } & \multirow{2}{*}{ Horizon } & \multirow{2}{*}{$\begin{array}{l}\text { Depth } \\
(\mathrm{cm})\end{array}$} & \multirow{2}{*}{$\mathrm{pH}$} & \multicolumn{3}{|c|}{$\begin{array}{l}\text { Total concentration of the element } \\
\left(\mathrm{mg} \mathrm{kg}^{-1}\right) \text { of dried mass of soil }\end{array}$} \\
\hline & & & & $\mathrm{Cu}$ & $\mathrm{Pb}$ & $\mathrm{Zn}$ \\
\hline \multirow{6}{*}{$1 \mathrm{ZM}$} & $\mathrm{O}$ & $4-0$ & 6.6 & 678 & 213 & 72 \\
\hline & Ap & $0-10$ & 5.4 & 16 & 22 & 26 \\
\hline & Bv1 & $10-30$ & 4.9 & 9 & 24 & 35 \\
\hline & Bv2 & $30-45$ & 4.9 & 9 & 35 & 26 \\
\hline & $\mathrm{BvC}$ & $45-60$ & 6.9 & 9 & 29 & 28 \\
\hline & $2 \mathrm{C}$ & $60+$ & 7.9 & 5 & 29 & 16 \\
\hline \multirow{8}{*}{$2 \mathrm{ZM}$} & $\mathrm{O}$ & $4-0$ & 6.5 & 365 & 119 & 65 \\
\hline & Ap1 & $0-10$ & 7.0 & 34 & 33 & 16 \\
\hline & Ap2 & $10-20$ & 7.1 & 9 & 30 & 20 \\
\hline & Ap3 & $20-30$ & 5.0 & 12 & 27 & 15 \\
\hline & Bv1 & $35-45$ & 5.4 & 5 & 18 & 15 \\
\hline & $\mathrm{Bv} 2$ & $45-60$ & 5.3 & 5 & 19 & 14 \\
\hline & $\mathrm{BvC}$ & $70-80$ & 4.8 & 6 & 20 & 17 \\
\hline & $\mathrm{C}$ & $90-100$ & 4.9 & 6 & 20 & 18 \\
\hline \multirow{7}{*}{$3 \mathrm{ZM}$} & $\mathrm{O}$ & $5-0$ & 6.3 & 115 & 62 & 50 \\
\hline & Ap1 & $0-10$ & 6.6 & 35 & 47 & 17 \\
\hline & Ap2 & $10-20$ & 6.0 & 25 & 45 & 15 \\
\hline & Ap3 & $28-38$ & 5.8 & 17 & 46 & 14 \\
\hline & $\mathrm{Bv}$ & $38-60$ & 5.4 & 2 & 20 & 10 \\
\hline & BvCgg & $60-90$ & 5.5 & 2 & 19 & 8 \\
\hline & Cgg & $90-100$ & 6.5 & 1 & 19 & 4 \\
\hline
\end{tabular}

stand 1 ZM (Table 1), which could imply stable humification processes in O horizons under the oldest pine stands (Table 1). Decomposition of organic matter from coniferous trees cause acidification of the underlying mineral horizons (Finzi et al. 1998, BERGER et al. 2008).

Soils under coniferous tree stands in the surroundings of the copper ore tailings facility had lower $\mathrm{pH}$ than soils under poplar stands in the vicinity of the copper smelter, where the highest, sometimes even alkaline reaction in distilled water was found at site $3 \mathrm{HML}$ (Table 2). The $\mathrm{pH}$ values of soils in the former impact zone of the copper smelter increased with the distance from the emitter, which could confirm the spatial distribution of airborne dust from the smelter. Dust speciation studies were not performed during 
Table 2

Chemical properties of forest soils in the surrounding of the copper smelter

\begin{tabular}{|c|c|c|c|c|c|c|}
\hline \multirow{2}{*}{ Profile } & \multirow{2}{*}{ Horizon } & \multirow{2}{*}{$\begin{array}{l}\text { Depth } \\
(\mathrm{cm})\end{array}$} & \multirow[t]{2}{*}{$\mathrm{pH}$} & \multicolumn{3}{|c|}{$\begin{array}{l}\text { Total concentration of the element } \\
\left.(\mathrm{mg} \mathrm{kg})^{-1}\right) \text { of dried mass of soil }\end{array}$} \\
\hline & & & & $\mathrm{Cu}$ & $\mathrm{Pb}$ & $\mathrm{Zn}$ \\
\hline \multirow{9}{*}{$1 \mathrm{HML}$} & $\mathrm{O}$ & $6-0$ & 6.7 & 13143 & 9181 & 3363 \\
\hline & Ap1 & $0-10$ & 7.1 & 2375 & 681 & 1488 \\
\hline & Ap2 & $10-20$ & 7.2 & 2875 & 723 & 327 \\
\hline & Ap3 & $20-30$ & 7.1 & 1065 & 259 & 132 \\
\hline & EBtg1 & $30-50$ & 7.1 & 20 & 37 & 35 \\
\hline & EBtg2 & $50-65$ & 7.3 & 13 & 12 & 37 \\
\hline & $\mathrm{Btg} C$ & $65-80$ & 7.4 & 9 & 26 & 26 \\
\hline & $2 \mathrm{C} 1$ & $85-95$ & 7.4 & 8 & 25 & 20 \\
\hline & $2 \mathrm{C} 2$ & $95-105$ & 7.4 & 9 & 20 & 16 \\
\hline \multirow{8}{*}{$2 \mathrm{HML}$} & $\mathrm{O}$ & $2-0$ & 6.8 & 1508 & 833 & 748 \\
\hline & Ap1 & $0-10$ & 6.9 & 439 & 183 & 91 \\
\hline & Ap2 & $10-20$ & 7.2 & 458 & 202 & 99 \\
\hline & Ap3 & $20-35$ & 7.4 & 423 & 165 & 77 \\
\hline & EBt & $35-55$ & 7.4 & 11 & 16 & 35 \\
\hline & Btg & $55-75$ & 7.4 & 11 & 14 & 37 \\
\hline & BtgC & $75-90$ & 7.4 & 8 & 12 & 25 \\
\hline & $2 \mathrm{C}$ & $95-110$ & 7.2 & 17 & 13 & 28 \\
\hline \multirow{9}{*}{$3 \mathrm{HML}$} & $\mathrm{O}$ & $2-0$ & 6.9 & 855 & 585 & 718 \\
\hline & Ap1 & $0-10$ & 6.7 & 200 & 92 & 55 \\
\hline & Ap2 & $10-20$ & 7.1 & 207 & 95 & 61 \\
\hline & Ap3 & $20-30$ & 7.3 & 208 & 95 & 63 \\
\hline & Eet & $30-45$ & 7.5 & 14 & 15 & 34 \\
\hline & EBt1 & $45-60$ & 7.6 & 14 & 13 & 31 \\
\hline & EBt2 & $60-75$ & 7.7 & 9 & 10 & 23 \\
\hline & BtC & $75-95$ & 7.7 & 9 & 10 & 20 \\
\hline & $\mathrm{C} 1$ & $95-105$ & 7.7 & 8 & 9 & 17 \\
\hline
\end{tabular}

this project but the increasing concentration of calcium and magnesium in $\mathrm{O}$ horizons at sites more distant from the smelter can prove these processes. Similar dependence was observed by Derome and Nieminen (1998) near the Harjavalta smelter in Finland. Under the poplar standings (HML) near the copper smelter, higher $\mathrm{pH}$ values were found in topsoil $(0-30 \mathrm{~cm})$ than 
in organic layers. This can suggest strong decomposition processes causing acidification of the material or the acidifying effect of $\mathrm{SO}_{4}^{-}$emission from the smelter on forest litter. In all the examined soil profiles in the surroundings of the copper smelter, the $\mathrm{pH}$ increased with the depth (Table 2), reaching the highest values in the $\mathrm{C}$ horizon. High $\mathrm{pH}$ values in deeper horizons are typical for Cutanic Luvisols, but can also be the effect of previous calcium and magnesium fertilization used while planting poplar trees.

The total concentrations of $\mathrm{Cu}, \mathrm{Pb}$ and $\mathrm{Cd}$ varied between the sites and within the soil profiles. The total $\mathrm{Cu}, \mathrm{Pb}$ and $\mathrm{Zn}$ concentrations were much higher in forest soils under poplar stands in the vicinity of the copper smelter than in soils impacted by the copper ore tailings facility (Tables 1,2). This can be the evidence that the copper smelter is a bigger source of heavy metal pollution for soils than the copper ore tailings facility. The average heavy metal concentration in soils in the surroundings of the copper ore tailings facility reached $678 \mathrm{mg} \mathrm{Cu} \mathrm{kg}-1,213 \mathrm{mg} \mathrm{Pb} \mathrm{kg}-1$ and $72 \mathrm{mg} \mathrm{Zn} \mathrm{kg}^{-1}$ in $\mathrm{O}$ horizon and was much lower than found by KRZAKLEwSKI et al. (2004) for soils impacted by dusting from the zinc-lead ore tailings facility in southern Poland, but much higher than found in soils under natural boreal ecosystems of Poland (GWOREK, DEGÓRSKI 1997). No significant differences were found in the $\mathrm{Cu}$ and $\mathrm{Zn}$ concentration in the topsoil of the ZM sites. Significant differences were only found for the $\mathrm{Pb}$ concentration between site $3 \mathrm{ZM}$ and 1 and $2 \mathrm{ZM}$.

In all the examined forest soils, the highest total concentration of all the analyzed elements was found in humus layers (Tables 1,2). Under the coniferous forest $1 \mathrm{ZM}$, the $\mathrm{Cu}$ concentration was even thirty-fold higher in ectohumus than in the mineral Ap horizon. Such relations were also found for $\mathrm{Pb}$ and $\mathrm{Zn}$ at all the forest sites. There were significant differences* in heavy metal contamination in forest ectohumus horizons between the sites in the surroundings of the copper tailings facility. The highest concentrations of all the heavy metals in ectohumus were found under the oldest pine stand $1 \mathrm{ZM}\left(678 \mathrm{mg} \mathrm{Cu} \mathrm{kg}-1,213 \mathrm{mg} \mathrm{Pb} \mathrm{kg}^{-1}\right.$ and $72 \mathrm{mg} \mathrm{Zn} \mathrm{kg}^{-1}$ in $\mathrm{O}$ horizon) and the lowest - under the youngest pine stand $3 \mathrm{ZM}(115 \mathrm{mg}$ $\mathrm{Cu} \mathrm{kg}{ }^{-1}, 62 \mathrm{mg} \mathrm{Pb} \mathrm{kg}{ }^{-1}, 50 \mathrm{mg} \mathrm{Zn} \mathrm{kg}{ }^{-1}$ in O horizon). Surprisingly high concentrations of $\mathrm{Cu}$ and $\mathrm{Pb}$ in $\mathrm{O}$ horizon under the oldest tree stand did not correspond with a higher content of the elements in the $0-30 \mathrm{~cm}$ mineral topsoil, what can prove that a well-developed, (proto)moder ectohumus horizon was an effective $\mathrm{Cu}$ and $\mathrm{Pb}$ filter (Table 1).

With respect to vertical concentrations of the elements downwards the soil profiles, the $\mathrm{Cu}$ content decreased and there was a significant difference between the $0-30 \mathrm{~cm}$ depth and deeper horizons. The $\mathrm{Zn}$ concentration also decreased with the depth into the soil profile but the differences were smaller. Changes in the $\mathrm{Pb}$ concentration were very irregular and there were no

*Tested with Tukey's test 
significant differences between horizons. Higher $\mathrm{Cu}$ and $\mathrm{Pb}$ concentrations in the topsoil were found under younger tree stands (18 and 11 years old), which can suggest poorer retention abilities of ectohumus horizons in the early stage of development. Unlike $\mathrm{Zn}, \mathrm{Cu}$ and $\mathrm{Pb}$ are strongly bound to organic matter and are not readily leached from the organic horizon (BERG 1986, BerGKVIST 1987). The total Zn concentration in the soil profiles under the pine stands depended more strongly on the level of contamination in ectohumus horizons than on the development stage, which can be also a proof of higher zinc leaching from $\mathrm{O}$ horizons. The concentrations of $\mathrm{Cu}, \mathrm{Pb}$ and $\mathrm{Cd}$ in soils in the vicinity of copper smelter decreased rapidly with the distance from the smelter and at $2.1 \mathrm{~km}(3 \mathrm{HML})$ the concentration of $\mathrm{Cu}$ in $\mathrm{O}$ horizons was 15 -fold lower than at $0.5 \mathrm{~km}$ from the emitter (1 HML). The differences between the sites were statistically significant*. Extremely high concentrations of heavy metals, reaching $13143 \mathrm{mg} \mathrm{Cu} \mathrm{kg}{ }^{-1}, 9181 \mathrm{mg} \mathrm{Pb}$ $\mathrm{kg}^{-1}$ and $3363 \mathrm{mg} \mathrm{Zn} \mathrm{kg}-1$ in $\mathrm{O}$ horizon, were found at the site $0.5 \mathrm{~km}$ (1 HML) from the smelter (Table 2). The concentrations of all the analyzed heavy metals decreased rapidly with depth in the soil profile, being even 1460 -fold lower in the $\mathrm{C}$ horizon (for $\mathrm{Cu}$ at site1 HML). The concentration of copper in the Ap soil horizon of at $1 \mathrm{HML}$ was six-fold lower than in $\mathrm{O}$ horizon, which verifies the role of ectohumus horizons in heavy metal retention. The highest accumulation rate was found for $\mathrm{Cu}$ and $\mathrm{Pb}$, whose concentrations in $\mathrm{O}$ horizon were six- and twelve-fold higher, respectively, than in the 0-30 $\mathrm{cm}$ topsoil (at site $1 \mathrm{HML}$ ).

At sites 2 and 3 HML, the difference was smaller (Table 2). Surprisingly, at site $1 \mathrm{HML}$ zinc was mostly accumulated in $\mathrm{O}$ horizon, but also very high zinc amounts (only two-fold lower) were found at the $0-10 \mathrm{~cm}$ depth. At the depth of 10-20 cm the concentration was ten-fold lower and at 20-30 cm - it was twenty-five-fold lower (Table 2). This stratification pattern was only found for forest soil at site $1 \mathrm{HML}$, highly contaminated with $\mathrm{Zn}$. At site $1 \mathrm{HML}$, the differences in the $\mathrm{Cu}$ and $\mathrm{Pb}$ content in deeper soil layers were also significant. No such regularities were found for the other sites ( 2 and 3 HML), where elemental concentrations decreased with the depth, but there were no significant differences between the sites. In all the forest soils under poplar stands, concentration of the elements in the mineral horizon depended more strongly on the distance from the smelter and different heavy metal content in ectohumus horizons, whereas the stage of development played a secondary role in $\mathrm{Cu}, \mathrm{Pb}$ or $\mathrm{Zn}$ retention.

These observations indicate the importance of afforestation in the capture of pollutants but also point to significant changes in the circulation of trace elements due to introduction of trees, as well as very specific forest soils. The most characteristic element of forest soils is the occurrence of organic layer, highly capable of metal sorption, which on the one hand hin-

*Tested with Tukey's test 
ders leaching of metals from the soil, but on the other hand causes major disturbances in processes of decomposition and humification of organic matter. O horizons of forest and afforested soils are often compared to a natural sink for heavy metals (TYLER 1973, BREYMeYER et al. 1997, WiLCKE et al. 1998, Berg 2000, Lomander, Johansson 2000). Reviews of filtration and accumulation abilities of forest soil organic horizons are usually based only on analysis of the total accumulation of metals in humus. Meanwhile, its sorption capacity depends on the type of forest humus, the dynamics of its distribution and chemical forms of elements reaching the horizon. The mechanisms of these processes and their actual impact on the cycling of elements in forest ecosystems are not yet well understood, although several important publications identified some aspects of them (BERGKVIST et al. 1987, DzIADOWIEC 1990, Berg et al. 1991, Derome, Nieminen 1998, Andersen et al. 2004, Mertens et al. 2007). The concentration of $\mathrm{Cu}, \mathrm{Pb}$ and $\mathrm{Zn}$ was higher than found in the vicinity of the objects on arable soils (Bulletin... 2009). This can be the evidence of a secondary rise in heavy metal concentration in the topsoil caused by the presence of tree stands and O horizons. Similar dependence was found by KABAŁA et al. (2008) in forest soils in the vicinity of a copper smelter in Głogów, SW Poland. Forest ecosystems are mainly closed systems, where all elements are cycled along internal pathways, so losses of trace elements, e.g. heavy metals, are very low. In contrast to arable land, the biomass (with a given content of metals) produced in a forest throughout a year is not removed from the ecosystem. This gradually leads toelevated concentration of heavy metals in the topsoil (KABA£A et al. 2008).

\section{CONCLUSIONS}

1. Forest ectohumus horizons, its stage of development and type, play a significant role in $\mathrm{Cu}, \mathrm{Pb}$ and $\mathrm{Zn}$ accumulation from airborne copper mining and smelting emissions.

2. In highly polluted soils with heavy metals, the total concentration of the elements in ectohumus reflects the amounts in mineral horizons.

3 . The wealth of tree stands can lead to bioaccumulation of heavy metals in forest soils.

\section{REFERENCES}

Andruszczak A., Straczyński S., Czerniawska W., Radwan B. 1986. Element content in soils and plan cultivated in the surrounding of copper smelters. Soil Sci. Ann., 37(4): 47-66. (in Polish)

Andersen M., Raulund-Rasmussen K., Strobel B., Hansen H. 2004. The effect of tree species and site on the solubility of $\mathrm{Cd}, \mathrm{Cu}, \mathrm{Ni}, \mathrm{Pb}$ and $\mathrm{Zn}$ in soils. Water, Air Soil Pollution, 154: 357-370. DOI:10.1023/B:WATE.0000022991.59456.01. 
Angezow Z. Chodak T., Kabala C., Kaszubkiewicz J., Szerszeń L. 2000. Impact of copper ore tailings facility in Żelazny Most on soils. Agricultural University of Poznań Annual, 317: 327-337. (in Polish)

BERG B. 1986. Nutrient release from litter and humus in coniferous forest soils - a mini review. Scan. J. For. Res., 1: 359-369.

Berg B., Еквонм G., Soderstrom B. Staff H. 1991. Reduction of decomposition rates of Scots Pine needle litter due to heavy-metal pollution. Water, Air Soil Pollution, 59: 165-177. DOI: 10.1007/BF00283179

BERG B. 2000. Litter decomposition and organic matter turnover in Northern Forest Soils. Forest Ecol. Managem., 133: 13-22. DOI: 10.1016/S0378-1127(99)00294-7

Berger T., Untersteiner H., Schume H., Jost G. 2008. Throughfall fluxes in a secondary spruce (Picea abies), a beech (Fagus sylvatica) and a mixed spruce-beech stand. Forest Ecol. Managem., 255: 605-618. DOI: 10.1016/j.foreco.2007.09.030

BERGKVIST B. 1987. Soil solution chemistry and metal budgets of spruce forest ecosystems in South Sweden. Water, Air Soil Pollution, 33: 131-154.

Bergkvist B., Folkeson L., Berggren D. 1989. Fluxes of $\mathrm{Cu}, \mathrm{Zn}, \mathrm{Pn}, \mathrm{Cd}$ and $\mathrm{Ni}$ in temperate forest ecosystems. A literature review. Water Air Soil Pollut., 47:217-286. DOI: 10.1007/ BF00279328

Bulletin of Environmental Protection KGHM 2009. Edt. by KGHM Polska Miedź S.A. (in Polish)

BReymeyer A., DegóRski M., REed D. 1997. Decomposition of pine-litter organic matter and chemical properties of upper soil layers: transect studies. Environ. Pollut., 98/3: 361-367. http:// dx.doi.org/10.1016/S0269-7491(97)00157-7

Carter M., Gregorich E. 2008. Soil sampling and methods of analysis. $2^{\text {nd }}$ Ed. Canadian Society of Soil Science, CRC Press.

Derome, T. Nieminen 1998. Metal and macronutrient fluxes in heavy-metal polluted Scots Pine ecosystems in SW Finland. Environ. Pollution, 103: 219-22. http://dx.doi.org/ 10.1016/S0269-7491(97)00157-7

Dziadowiec H. 1990. Litter decomposition in forest ecosystems. Edt. by Mikołaj Kopernik University in Torun. (in Polish)

Finzi A., Canham C., Van Breemen N. 1998. Canopy-tree interactions within temperate forests: species effect on $p H$ and cations. Ecol. Appl., 8: 447-454. DOI 10.1890/10510761

Gworek B., Degónski M. 1997. Spatial and profile distribution of iron and trace elements in soils under boreal ecosystems. Soil Sci. Annual, 48, 1/2: 19-30. (in Polish)

Hossner L. 1996. Dissolution for total analysis. In: Methods of soil analysis. Part 3. Chemical methods. BARTELs J.M. (ed.) Soil Sci. Soc. America, Madison, Wisconsin, USA, 49-64.

Kabaza C., Chodak T., Szerszeń L. 2008. Influence of land use pattern on changes in copper content in soils around a copper smelter, based on a 34-year monitoring cycle. Tुemës Ükio Mokslai, 15(3): 8-12

Karczewska A., Kaszubiewicz J., Jeziersiki P., Kabąa C., Król K. 2010. Copper, lead and cadmium concentration in soils of Legnica smelter protective zone, in years 1982-2005. Soil Sci. Annual, 61(1): 45-51. (in Polish)

Krzaklewski W., Barszcz J., Mąek S., Kozio€ K., Pietrzykowski M. 2004. Contamination of forest soil in the vicinity of the sedimentation pond after zinc and lead ore flotation (in the region of Olkusz, southern Poland). Water, Air Soil Pollution, 159: 151-164. DOI: 10.1023/B:WATE.0000049173.18935.71

Lomander A., Johansson M. 2001. Changes in concentration of $\mathrm{Cd}, \mathrm{Zn}, \mathrm{Mn}, \mathrm{Cu}$ and $\mathrm{Pb}$ in spruce (Picea abies) needle litter during decomposition. Water, Air Soil Pollution, 132: 165-184. DOI: 10.1023/A:1012035620480 
Medyńska A., Kabaza C., Chodak T., Jezierski P. 2009. Concentration of copper, zinc, lead and cadmium in plants in the surroundings of Żelazny Most copper ore tailings impoundment. J. Elementol., 14(4): 729-736.

Mertens J., Van Nevel L., De SchriJver A., Piesschaert F., Oosterbaan A., Tack F. M.G., Verheyen K. 2007. Tree species effect on the redistribution of soil metals. Environ. Pollut., 149: 173-181. http://dx.doi.org/10.1016/j.envpol.2007.01.002

Monograph of KGHM Polish Copper Company 2007. Ed. by KGHM Cuprum Sp.z.o.o. Research Center, Wrocław Poland. (in Polish)

Szerszeń L., ChODAK T., KABAŁA C. 1999. Monitoring studies of trace element concentration in soils impacted by copper smelters in Gtogów and Legnica. Adv. Agric. Sci. Problem Issues, 467: 405-412. (in Polish)

Szerszeń L., Chodak T., Kabąa C. 2004. Changes in copper, lead and zinc concentration in soils impacted by copper smelters Gtogów and Legnica in years 1972-2002. Soil Sci. Annual, 55(3): 195-205. (in Polish)

Świercz A. 2003. Heavy metal concentration in needles and bark of Pinus Sylvestris after decrease of alkaline emission. Regional Monitoring of Natural Ecosystems, 4: 107-113. Ed. by Kieleckie Towarzystwo Naukowe, Kielce. (in Polish)

TYLER G. 1973. Heavy metal pollution and decomposition of spruce needle litter. Oikos, 24: 402-416.

Ukonmanaho L., Starr M., Mannio J., Ruoho-Airola T. 2001. Heavy metal budgets for two headwater forested catchments in background areas of Finland. Environ. Pollut., 114: 63-75.

Wilcke W., Mosbach J., Ков•А J., Zесн W. 1998. Distribution of Al and heavy metals in bulk soil and aggregates at three sites contaminated by the emissions of a central Slovak al smelter. Water, Air, Soil Pollution, 106: 389-402. DOI: 10.1023/A:1005094624006.

World Soil Resources Reports No. 103. FAO, Rome. 